\title{
Pressure and cold pain threshold in healthy subjects undergoing interferential current at different amplitude modulated frequencies*
}

\author{
Avaliação do limiar de dor à pressão e ao frio em indivíduos saudáveis submetidos à corrente \\ interferencial em diferentes frequências de amplitude modulada
}

Alexandra de Oliveira Claro¹, Bruna Akie Kanezawa1, Michele de Camargo¹, Vanessa Maria Paes ${ }^{1}$ José Luiz Marinho Portolez², Gladson Ricardo Flor Bertolini ${ }^{1}$

${ }^{*}$ Received from the Laboratory to Study Injuries and Physiotherapeutic Resources, State University of Western Paraná, Cascavel, PR, Brazil.

DOI 10.5935/1806-0013.20140039

\section{ABSTRACT}

BACKGROUND AND OBJECTIVES: The interferential current is an electrical stimulation method widely used with analgesic purposes; however, there are controversies regarding their usage parameters. The aim of this study was to compare different amplitude modulated frequencies of the interferential current on the pressure and cold pain threshold in healthy volunteers.

METHODS: This is a crossover, randomized and blinded evaluators and evaluated in quantitative character test. Participants were 20 volunteers divided into four groups, who for four weeks were subject to different modulated frequencies. Thresholds of pressure and cold pain in four different times were evaluated - at the beginning, right after electric stimulation, 20 and 60 minutes after. As a form of electrical stimulation, interferential current was used at modulated amplitude frequencies of $1 \mathrm{~Hz}$, $10 \mathrm{~Hz}$ and $100 \mathrm{~Hz}$ with base frequency of $4,000 \mathrm{~Hz}$, being that in a particular week volunteers received placebo $(0 \mathrm{~Hz})$.

RESULTS: There has been no significant difference in comparisons within frequencies or between them and the placebo group. CONCLUSION: The use of amplitude modulated frequencies of interferential current of $1 \mathrm{~Hz}, 10 \mathrm{~Hz}$ and $100 \mathrm{~Hz}$ did not change cold and pressure pain thresholds, similar to what has been found for the placebo group

Keywords: Analgesia, Pain measurement, Transcutaneous electric nerve stimulation.

\footnotetext{
1. Federal University of Western Paraná, Course of Physiotherapy, Cascavel, PR, Brazil. 2. Santa Cecilia University, Course of Physiotherapy, Santos, SP, Brazil.

Submitted in April 08, 2014.

Accepted for publication in August 22, 2014.

Conflict of interests: none.

Correspondence to:

Gladson Ricardo Flor Bertolini

Rua Universitária, 2069 - Jardim Universitário

85819-110 Cascavel, PR, Brasil.

E-mail: Gladson_ricardo@yahoo.com.br

(C) Sociedade Brasileira para o Estudo da Dor
}

\section{RESUMO}

JUSTIFICATIVA E OBJETIVOS: A corrente interferencial é um método de eletroestimulação bastante utilizado com finalidades analgésicas, porém, existem controvérsias com relação aos seus parâmetros de uso. O objetivo do estudo foi comparar diferentes frequências de amplitude modulada, da corrente interferencial, sobre o limiar de dor à pressão e ao frio, em voluntários saudáveis.

MÉTODOS: Trata-se de um ensaio cruzado, aleatório e com avaliadores e avaliados encobertos, de caráter quantitativo. Participaram deste estudo 20 voluntários subdivididos em quatro grupos, que durante quatro semanas passaram por diferentes frequências de amplitude modulada. Foram avaliados os limiares da dor à pressáo e ao frio em quatro momentos distintos - no início, logo após eletroestimulação, 20 e 60 minutos após. Como forma de eletroestimulação foi utilizada a corrente interferencial nas frequências de amplitude modulada de $1 \mathrm{~Hz}, 10 \mathrm{~Hz}$ e $100 \mathrm{~Hz}$, com frequência de base de $4.000 \mathrm{~Hz}$, sendo que em uma determinada semana os voluntários recebiam placebo $(0 \mathrm{~Hz})$.

RESULTADOS: Não houve diferença significativa nas comparaçóes dentro das frequências, nem entre elas e o grupo placebo. CONCLUSÁO: O uso da corrente interferencial nas frequências de amplitude modulada de $1 \mathrm{~Hz}, 10 \mathrm{~Hz}$ e $100 \mathrm{~Hz}$ não produziu alteraçôes nos limiares de dor ao frio e à pressão, semelhante ao encontrado para o grupo placebo.

Descritores: Analgesia, Estimulaçáo elétrica nervosa transcutânea, Mensuração da dor.

\section{INTRODUCTION}

The International Society for the Study of Pain (IASP) defines pain as "a sensory, emotional and unpleasant experience, related to tissue injury or described in such terms". It is a manifestation involving physical, psychic and cultural mechanisms, should be considered the fifth vital sign and as such should be measured and recorded ${ }^{1}$. So, methods are used to quantify pain intensity, among them pressure algometry, which is a power transducer requiring perceptive response of the evaluated patient, being very useful in the evaluation of clinical trials ${ }^{2}$. 
Other experimental pain models are used to represent pain, such as cold-induced pain, which is a simple method involving minimum risk of tissue injury and pain stops after removal of the stimulus. During such test, a painful sensation is generated by temperature receptors which start sending stimuli of a possible tissue injury through peripheral and central pathways, resulting in cold-induced pain sensation ${ }^{3}$.

Since pain is still the primary reason for looking for medical aid, analgesic techniques are developed and studied, such as the use of interferential current. This is commonly used as electric stimulation, the primary clinical use of which is to relieve pain ${ }^{4,5}$. This current has effect on decreasing pain intensity by significantly increasing pain threshold and may even block nervous conduction ${ }^{6-8}$. However, there are controversies about interferential current effectiveness with some studies showing positive results ${ }^{9}$ and others negative results ${ }^{10}$, which is often caused by different pain evaluation methods or by differences in stimulation parameters.

So, there is need for studies evaluating current efficacy on different pain threshold types, as well as the diversity of therapeutic parameters commonly used for interferential current, such as, whether low amplitude modulated frequencies (AMF) have any kind of influence on analgesic mechanisms. So, this study aimed at comparing the effect of different interferential current AMFs on pressure and cold pain threshold, determining the effectiveness of the electric current to promote analgesia by increasing pain threshold in healthy individuals.

\section{METHODS}

This is a crossover, randomized and quantitative trial with blind evaluating and evaluated individuals. Participated in the study 20 volunteers, being 13 females and 7 males, with mean age of $20.35 \pm 1.725$ years, weight $63.95 \pm 12.03 \mathrm{~kg}$, height $1.695 \pm 0.1073 \mathrm{~m}$ and body mass index (BMI) of $22.13 \pm 2.714$ $\mathrm{kg} / \mathrm{m}^{2}$. Volunteers have signed the Free and Informed Consent Term (FICT), where they agreed in participating in the study without any compensation and were informed that they could quit the study at any time by free will.

Individuals with any contraindication to the use of electric stimulation, in addition to contraindications to cold and heat were excluded.

Volunteers were randomly divided in four groups of 5 individuals each: group 1 (G1), group 2 (G2), group 3 (G3) and group 4 (G4). Individuals have always performed the same activities within the group, in four consecutive weeks and in crossover manner, that is, each group has gone through all different types of frequencies in different weeks. This way, all volunteers were submitted to all types of electric stimulation and placebo.

\section{Evaluation protocol}

Different transcutaneous AMFs were evaluated: $0 \mathrm{~Hz}, 1 \mathrm{~Hz}$, $10 \mathrm{~Hz}$ and $100 \mathrm{~Hz}$, with bipolar technique and base frequency of $4000 \mathrm{~Hz}$, on pressure and cold pain thresholds. For such, volunteers have participated in an initial evaluation (EV1), before being undergoing electric stimulation.

Previously to initial evaluation, volunteers have immersed their left arm until the elbow joint interline, in a container with water at $38^{\circ} \mathrm{C}$ (Inconterm ${ }^{\circledast}$ thermometer) for 5 minutes, aiming at homogenizing sample temperature. Soon after arm drying, pressure pain threshold was evaluated (Algometer Kratos $^{\oplus}$ with capacity to produce up to $50 \mathrm{Kgf}$, with sharp metal tip). It was explained that they should report the exact moment when they felt pain. Sites to apply the algometer were: $1 \mathrm{~cm}$ distal to pisiform bone in hypothenar region and $1 \mathrm{~cm}$ distal to scaphoid bone in thenar region. Pressure was gradually increased and removed as soon as the volunteer reported pain.

Cold-induced pain was evaluated three minutes after pressure pain threshold evaluation. Volunteers immersed the left hand in a container with water and ice $\left(5^{\circ} \mathrm{C}\right)$ until wrist joint interline. Individuals were asked to report pain sensation as soon as they felt it, time was measured as from the moment volunteers immersed their hand in cold water and as soon as they said the word "pain", this time was recorded as cold pain threshold.

Such evaluations were repeated immediately after using interferential current (EV2), 20 (EV3) and 60 (EV4) minutes after. In all evaluation moments, the evaluator did not know with AMF frequency the volunteer would receive or had received.

\section{Electric stimulation protocol}

Rubber-silicone $8 \mathrm{~cm}^{2}$ electrodes were used, coupled to patients with water-soluble gel and fixed with adhesive tape; equipment used was Neurovector (Ibramed $^{\circledast}$ ). Since this was a crossover study, volunteers were initially distributed in one of 4 groups. In the first week, they went through a certain frequency, in the following week they were submitted to a different frequency, and so on, until the end of the 4 proposed weeks:

- $0 \mathrm{~Hz}$ - placebo moment when no current was emitted to volunteer;

- $1 \mathrm{~Hz}$ - equipment produced $1 \mathrm{~Hz}$ AMF;

- $10 \mathrm{~Hz}-10 \mathrm{~Hz}$ AMF;

- $100 \mathrm{~Hz}-100 \mathrm{~Hz}$ AMF.

Electric stimulation was performed for 20 minutes, with electrodes located on elbow joint, being one positioned on the ulnar nerve sulcus (ulnar nerve superficiality) and the other on the cubital face (median nerve superficiality), with intensity considered high, however not painful. Asepsis was performed with cotton soaked in $70 \%$ alcohol on application site, previous to electrodes placement.

\section{Statistical analysis}

Data normality was analyzed with Kolmogorov-Smirnov test and comparisons were analyzed by ANOVA for repeated measures with significance level of $5 \%$.

The study was approved by the Ethics and Research Committee, State University of Western Paraná 143/2013. 
Table 1. Values for algometer pressure in grams (g), for different groups

\begin{tabular}{lcccc}
\hline & $\mathrm{OHz}$ & $1 \mathrm{~Hz}$ & $10 \mathrm{~Hz}$ & $100 \mathrm{~Hz}$ \\
\hline AV1 & $0.776 \pm 0.412$ & $0.835 \pm 0.425$ & $0.777 \pm 0.458$ & $0.813 \pm 0.455$ \\
AV2 & $0.764 \pm 0.368$ & $0.814 \pm 0.349$ & $0.695 \pm 0.353$ & $0.836 \pm 0.459$ \\
AV3 & $0.767 \pm 0.357$ & $0.780 \pm 0.380$ & $0.760 \pm 0.448$ & $0.747 \pm 0.401$ \\
AV4 & $0.738 \pm 0.382$ & $0.747 \pm 0.351$ & $0.755 \pm 0.397$ & $0.779 \pm 0.423$ \\
\hline
\end{tabular}

(OHz: placebo, $1 \mathrm{~Hz}, 10 \mathrm{~Hz}$ and $100 \mathrm{~Hz}$ ), in different evaluation moments (AV1: pre-stimulation; AV2: immediately after stimulation; AV3: 20 minutes after; AV4: 60 minutes after); with pressure on hypothenar eminence.

Table 2. Values for algometer pressure in grams (g), for different groups

\begin{tabular}{lcccc}
\hline & $0 \mathrm{~Hz}$ & $1 \mathrm{~Hz}$ & $10 \mathrm{~Hz}$ & $100 \mathrm{~Hz}$ \\
\hline AV1 & $0.599 \pm 0.293$ & $0.638 \pm 0.300$ & $0.614 \pm 0.283$ & $0.782 \pm 0.630$ \\
AV2 & $0.654 \pm 0.319$ & $0.658 \pm 0.310$ & $0.561 \pm 0.269$ & $0.681 \pm 0.338$ \\
AV3 & $0.718 \pm 0.363$ & $0.713 \pm 0.355$ & $0.641 \pm 0.263$ & $0.649 \pm 0.323$ \\
AV4 & $0.626 \pm 0.362$ & $0.654 \pm 0.352$ & $0.684 \pm 0.307$ & $0.670 \pm 0.319$ \\
\hline
\end{tabular}

(OHz: placebo, $1 \mathrm{~Hz}, 10 \mathrm{~Hz}$ and $100 \mathrm{~Hz}$ ), in different evaluation moments (AV1: pre-stimulation; AV2: immediately after stimulation; AV3: 20 minutes after; AV4: 60 minutes after); with pressure on thenar eminence.

Table 3. Values for cold pain threshold in seconds (s), for different groups

\begin{tabular}{lcccc}
\hline & $0 \mathrm{~Hz}$ & $1 \mathrm{~Hz}$ & $10 \mathrm{~Hz}$ & $100 \mathrm{~Hz}$ \\
\hline AV1 & $31.45 \pm 20.87$ & $43.95 \pm 37.49$ & $28.90 \pm 31.33$ & $28.35 \pm 21.42$ \\
AV2 & $46.10 \pm 72.65$ & $35.40 \pm 22.76$ & $28.50 \pm 30.93$ & $24.00 \pm 18.57$ \\
AV3 & $34.75 \pm 25.99$ & $40.15 \pm 23.67$ & $33.25 \pm 32.68$ & $33.75 \pm 51.35$ \\
AV4 & $35.15 \pm 23.38$ & $39.40 \pm 26.61$ & $34.55 \pm 50.83$ & $43.10 \pm 63.42$
\end{tabular}

(OHz: placebo, $1 \mathrm{~Hz}, 10 \mathrm{~Hz}$ and $100 \mathrm{~Hz}$ ), in different evaluation moments (AV1: pre-stimulation; AV2: immediately after stimulation; AV3: 20 minutes after; AV4: 60 minutes after).

\section{RESULTS}

There has been no significant difference in pressure pain threshold among different evaluations and also among different frequencies, both for thenar region pressure $(\mathrm{p}=0.2714)$ (Table 1) and for hypothenar region $(p=0.7645)$ (Table 2). Similarly, there has been no significant difference for cold pain threshold $(\mathrm{p}=0.5687)$ (Table 3$)$.

\section{DISCUSSION}

This study looked at comparing different interferential current AMFs on pressure and cold pain threshold, with strong, however pleasant stimulation. There were no significant differences in pressure and cold pain thresholds, regardless of the evaluation moment. This confirms previous study where authors have reported no significant changes in A delta and C fibers threshold when interferential current was applied to healthy individuals ${ }^{11}$. Similarly, a different study inducing cold pain in healthy individuals has not observed significant effect on pain threshold of individuals submitted to interferential current ${ }^{12}$. It is believed that this lack of positive effects (analgesia) is due exactly to the fact of not stimulating with painful current, that is, stimulation was not painful and this way there has been no inhibitory effect by descending pathways.

Notwithstanding studies showing poor results of interferen- tial current to control experimental pain, there are hints that it works as complementary therapy for pain relief, being more effective than placebo. However, since studies substantiating this are widely different, such hints should be taken with care $^{4}$. A study using interferential current with painful and non-painful stimulations in patients with chronic pain due to knee osteoarthritis, has observed that interferential current was effective for analgesia, but high intensity (painful) stimulation has produced more hypoalgesic effects as compared to sensory stimulation ${ }^{6}$.

A study evaluating the effect of interferential current on pressure and cold pain models, has observed hypoalgesia by electric stimulation, differently from what has been observed in our study, and authors mention that pain thresholds evaluation is enough for the observation of the effects of the current, with no need for higher intensities, which generate more discomfort and risks for injuries 9 . This way, in our study, although with different results from those already mentioned, we decided for evaluating just pain thresholds.

In healthy individuals, stimulation below pain threshold in cases of electric stimulation may be the differential between the production or not of hypoalgesic effects by using conventional TENS ${ }^{2}$ and also its burst form ${ }^{13}$. A study evaluating Bernard diadynamics in healthy individuals with non-painful intensities, also points to the lack of hypoalgesic effects of electric stimulation ${ }^{14}$. That is, with non-painful intensities, 
accepted as major stimuli for ascending analgesia, via gate, non-noxious stimulation was unable to produce pain threshold changes. However, authors show evidences that $80 \mathrm{~Hz}$ TENS increases pressure algometry threshold in healthy participants when a strong, however painless sensation is produced in the experimental pain site ${ }^{15}$.

In our study, we decided for two experimental ways to evaluate pain: pressure and cold. These ways have some advantages, such as better control of stimuli and conditions, in addition to helping the recording, which is important; however emotional aspects of individuals with clinical pain are not addressed ${ }^{1}$. So, we emphasized that the study had as limitation the fact that participants had no pain and also that the intensity used has not reached pain threshold. So it is suggested that further studies are carried out with individuals with chronic pain and/or using higher current intensities.

\section{CONCLUSION}

Interferential current at $1 \mathrm{~Hz}, 10 \mathrm{~Hz}$ and $100 \mathrm{~Hz}$ AMFs has not produced cold and pressure pain threshold changes, similarly to what was found for the placebo group.

\section{REFERENCES}

1. Silva JA, Ribeiro-filho NP. A dor como um problema psicofísico. Rev Dor. 2011;12(2):138-51.

2. Claydon LS, Chesterton LS, Barlas P, Sim J. Dose-specific effects of transcutaneous electrical nerve stimulation (TENS) on experimental pain. A systematic review. Clin J Pain. 2011;27(7):635-47.

3. Montenegro EJ, Albuquerque NB, Mariz LM, Costa RC, Montarroyos CS, Motta MA da. Açáo da TENS acupuntural em acupontos na dor induzida pela hipotermia local $\left(0-2^{\circ} \mathrm{C}\right)$. Fisioter Mov. 2010;23(3):483-92.

4. Fuentes JP, Olivo SA, Magee DJ, Gross DP. Effectiveness of interferential current therapy in the management of musculoskeletal pain: a systematic review and meta-analysis. Phys Ther. 2010;90(9):1219-38.

5. Poitras S, Brosseau L. Evidence-informed management of chronic low back pain with transcutaneous electrical nerve stimulation, interferential current, electrical muscle stimulation, ultrasound, and thermotherapy. Spine. 2008;8(1):226-33.

6. Defrin R, Ariel E, Peretz C. Segmental noxious versus innocuous electrical stimulation for chronic pain relief and the effect of fading sensation during treatment. Pain. 2005;115(1-2):152-60

7. Ward AR. Electrical stimulation using Kilohertz-frequency alternating current. Phys Ther. 2009;89(2):181-90.

8. Ward AR, Lucas-Toumbourou S, Mccarthy B. A comparison of the analgesic efficacy of medium-frequency alternating current and TENS. Physiotherapy. 2009;95(4):280-8.

9. McManus FJ, Ward AR, Robertson VJ. The analgesic effects of interferential therapy on two experimental pain models: cold and mechanically induced pain. Physiotherapy. 2006;92(2):95-102

10. Minder PM, Noble JG, Alves-Guerreiro J, Hill ID, Lowe AS, Walsh DM, et al. Interferential therapy: lack of effect upon experimentally induced delayed onset muscle soreness. Clin Physiol Funct Imaging. 2002;22(5):339-47.

11. Palmer ST, Martin DJ, Steedman WM, Ravey J. Effects of electric stimulation on C and A delta fiber - mediated thermal perception thresholds. Arch Phys Med Rehabil. 2004;85(1):119-28.

12. Johnson MI, Tabasam G. An investigation into the analgesic effects of different frequencies of the amplitude-modulated wave of interferential current therapy on cold-induced pain in normal subjects. Arch Phys Med Rehabil. 2003;84(9):1387-94.

13. Schulz AP, Chao BC, Gazola F, Pereira GD, Nakanishi MK, Kunz RI, et al. Açáo da estimulaçấo elétrica nervosa transcutânea sobre o limiar de dor induzido por pressão. Rev Dor. 2011;12(3):231-4.

14. Camargo BF, Santos MM, Liebano RE. Efeito hipoalgésico das correntes diadinâmicas de Bernard em indivíduos saudáveis. Rev Dor. 2012;13(4):327-31.

15. Chen C-C, Johnson MI. An investigation into the hypoalgesic effects of high- and low-frequency transcutaneous electrical nerve stimulation (TENS) on experimentally-induced blunt pressure pain in healthy human participants. J Pain. 2010;11(1):53-61. 